\title{
COMPARATIVE RESULTS OF COLLOIDAL MASTIC AND COLLOIDAL GOLD TESTS *
}

\author{
ALBERT KEIDEL, M.D., AND JOSEPH EARLE MOORE, M.D. \\ BALTIMORE
}

Although the colloidal mastic test, first introduced by Emmanuel, ${ }^{1}$ and later modified by Cutting, ${ }^{2}$ has been in limited use for several years, the question of its value as compared with that of the colloidal gold test is still an unsettled one. Considering the more complicated and uncertain methods of preparing the reagents used in the colloidal gold test, the simplicity and uniformity of the mastic reaction has much to recommend it. If it can be shown that the information provided by the mastic test is equivalent to that given by the gold test, or that the mastic test may in some cases provide information which the gold test fails to give, the test deserves wider use than is now made of it. In either case, the mastic test should prove of value not only when facilities for performing the gold test are lacking, but also as a check on the more complicated gold reaction in the laboratories where this test is now employed.

Both the gold and mastic reactions apparently depend on colloidal phenomena. The gold solution undergoes quantitative colorimetric changes leading up to complete precipitation, while the suspension of finely divided colloidal mastic particles undergoes quantitative flocculation, also culminating in complete precipitation. Resins other than mastic may be employed for the preparation of the colloidal suspension, the successful substitution depending on a proper adjustment of other reagents employed in the test, to balance variations in the amount of free acids present in other resins. It seems probable that these free acids exercise a dominating influence on the reaction.

Recent authors have thoroughly reviewed the literature, making a further complete survey unnecessary. Stanton ${ }^{3}$ and Camp ${ }^{4}$ conclude that the results obtained with the mastic test are in close agreement with those obtained with the gold test.

\footnotetext{
* From the Syphilis Department of the Medical Clinic, Johns Hopkins Hospital.

1. Emmanuel, G.: Eine neue Reaktion zur Untersuchungen des Liquor cerebrospinalis, Berl, klin. Wchnschr. 52:792, 1915.

2. Cutting, J. A.: A New Mastic Test for the Spinal Fluid, J. A. M. A. 68:1810 (June 16) 1917.

3. Stanton, J. M.: Concerning the Colloidal Mastic Test, Arch. Neurol. \& Psychiat. 4:301 (Sept.) 1920.

4. Camp, C.: Colloidal Mastic Test on Cerebrospinal Fluid, Am. J. Syph. 4:301, 1920 .
} 
In order to secure further information regarding this still unsettled point, we have studied the spinal fluids of 311 patients. Gold ${ }^{5}$ and mastic tests were compared with each other and with the cell counts, globulin reactions and Wassermann tests in all the fluids. The material is almost entirely from the syphilis department, and consists of fluids from patients exhibiting various forms of syphilis. A small number of fluids from nonsyphilitic patients, on whom puncture was performed to rule out neurosyphilis, has also been examined. Of the 311 fluids, there was complete agreement between the gold and mastic tests 234 times. In the remaining seventy-seven instances in which there was disagreement, the discrepancies have been analyzed.

\section{TECHNIC}

The technic which we have employed in the mastic test is that described by Stanton. ${ }^{3}$ It is essentially as follows: Ten grams of commercial gum mastic are dissolved in 100 c.c. of absolute alcohol, and the resultant cloudy fluid filtered several times until a clear straw colored solution is obtained. This stock solution is kept in glass stoppered bottles at room temperature. The emulsion is prepared with 1 c.c. of the stock solution added to 9 c.c. of absolute alcohol, which is then added, with gentle mixing, to 40 c.c. of once distilled water.

In setting up the test ten small tubes are employed. To the first tube in the series are added 1.5 c.c. of a stock salt solution ( 99 c.c. of 1.25 per cent. sodium chlorid solution plus 1 c.c. of 0.5 per cent. potassium carbonate solution), and to each of the remaining tubes 1 c.c. is added. In the first tube there is placed 0.5 c.c. of the spinal fluid to be tested. After mixing this dilution of spinal fluid, a titration is made throughout the series by transferring 1 c.c. from the first to the second tube, from the second to the third, etc., 1 c.c. being finally discarded from the last tube. Finally, 1 c.c. of the mastic emulsion is added to each tube. After mixing, the tubes are allowed to stand over night at room temperature, and the results are read in the morning. No special precautions regarding absolute cleanliness of glassware, such as are necessary for the gold test, need be observed.

In recording results, previous experimenters have used either the terms positive and negative, or, as later suggested by Smith, ${ }^{6}$ a numerical scale denoting degrees of flocculation and precipitation, as follows: No change is indicated by 0 ; loss of opalescence and very slight precipitation by 1 ; milky fluid with distinct precipitation by 2 ; marked precipitation with turbid fluid by 3 ; and complete precipitation by 4 .

5. The colloidal gold tests were all performed in the laboratory of the Phipps Psychiatric Clinic of this hospital, under the supervision of Dr. Phyllis Greenacre, for whose cooperation we are deeply grateful. The technic employed is that described by L. D. Felton in "A Study of the Specificity of the Colloidal Gold Reaction from the Physicochemical Standpoint," Trans. Sect. Path. and Physiol., A. M. A., 1917, p. 73.

6. Smith, E. R.: The Mastic Reaction on the Cerebrospinal Fluid, Med. Rec. 92:675, 1917. 
With this scale it is possible to chart curves which correspond in type to those of the gold test, but as they differ numerically, 4 denoting in the mastic test complete precipitation, which in the gold test is recorded as 5, we deemed it expedient as a preliminary to our work to construct a scale which would exactly correspond to that employed everywhere in the gold test. By observing the reactions obtained in a number of fluids in parallel series of gold and mastic tests the following scale was arrived at: 0 , opalescence, no change; 1 , milky fluid with no precipitation; 2 , milky fluid with slight precipitation; 3 , milky fluid with moderate precipitation; 4, cloudy fluid with almost complete precipitation; and 5 , clear fluid with complete precipitation. With this scale mastic reactions recorded as 2 may occur in normal fluids with about the same frequency as in the gold test, and such reactions are therefore regarded as within normal limits. Fluids which produce moderate precipitation, however, as denoted by a reading 3 , we have tentatively regarded as abnormal for reasons which will be given in the analysis of this type of reaction. Slight color changes occurring in normal fluids, as observed in the gold test, occur more frequently with some preparations of colloidal gold chlorid solutions than with others, but a color change reading as high as 3 is regarded as abnormal and is recorded as a syphilitic zone curve.

We have observed three types of curves with the mastic test: a paretic curve, a negative curve and a "mastic 3" curve. In only one instance was a curve of the gold syphilitic zone type observed. For the purpose of comparison with the gold reaction, we have arranged our results in seven groups as follows:

\section{RESULTS OF AUTHORS' TESTS}

Gold and Mastic Curves Both Negative.-In this group are 203 of the fluids examined. In general, there was complete agreement with the clinical findings and with the other tests of the cerebrospinal fluid. In only one instance was there a positive Wassermann reaction in the fluid with both colloidal tests negative; this was a fluid with 24 cells and a positive globulin reaction in a patient with secondary syphilis with irregular pupils and sluggish reflexes. Cell counts were not made in all fluids, but in thirteen instances there was an increased cell count or an increased globulin content or both. The diagnoses of the patients in this group were: primary syphilis, 11 ; secondary syphilis, 45; tertiary syphilis, 42 ; syphilis Wassermann, 34 ; latent syphilis, 7 ; congenital syphilis, 6; neurosyphilis (mostly treated cases), 21 ; undiagnosed (except in one instance all referred from other clinics for spinal puncture), 14; and nonsyphilitic patients, 23. The nonsyphilitic patients composed a diagnostic group including normal persons investi- 
gated for familial syphilis, neurasthenia, lethargic encephalitis, transverse myelitis and other neurologic affections. Practically all the syphilitic patients had received some treatment before the time of puncture, which probably accounts for some of the negative curves in those fluids showing other minor abnormalities.

TABle 1.-Gold and Mastic Curves Both Paretic*

\begin{tabular}{|c|c|c|c|c|c|c|c|c|c|}
\hline \multirow{3}{*}{$\begin{array}{l}\text { Case } \\
\text { No. }\end{array}$} & \multirow{3}{*}{$\begin{array}{c}\text { Diagnosis on } \\
\text { Admission. } \\
\text { Form of } \\
\text { Syphilis }\end{array}$} & \multirow{3}{*}{$\begin{array}{c}\text { Blood } \\
\text { Wasser- } \\
\text { mann } \\
\text { Reac- } \\
\text { tion }\end{array}$} & \multicolumn{7}{|c|}{ Cerebrospinal Fluid } \\
\hline & & & \multirow[b]{2}{*}{ Cells } & \multirow{2}{*}{$\begin{array}{l}\text { Glob- } \\
\text { ulin }\end{array}$} & \multicolumn{3}{|c|}{ Wassermann } & \multirow{2}{*}{$\begin{array}{l}\text { Gold } \\
\text { Curve }\end{array}$} & \multirow{2}{*}{$\begin{array}{l}\text { Mastic } \\
\text { Curve }\end{array}$} \\
\hline & & & & & $\begin{array}{c}0.2 \\
\text { C.c. }\end{array}$ & \begin{tabular}{r|}
0.4 \\
C.c.
\end{tabular} & $\begin{array}{l}1.0 \\
\text { C.c. }\end{array}$ & & \\
\hline B3 & $\begin{array}{l}\text { Central nervous } \\
\text { system, unclassed }\end{array}$ & 3 & N. C. & ++ & 4 & 4 & 4 & 5554410000 & 5554310000 \\
\hline$A \times 21$ & Wassermann & 4 & N. C. & ++ & 4 & 4 & 4 & 5555555221 & 5532100000 \\
\hline $\mathrm{Ax} 24$ & Tabes & 4 & N. C. & $++t+$ & 4 & 4 & 4 & 5555542100 & 5554321000 \\
\hline $\mathrm{Bx} 7$ & Tabes & 4 & N. C. & $+t+t$ & 4 & 4 & 4 & 5555582100 & 555432100 \\
\hline $\mathrm{Cx} 5$ & Paresis & 4 & N. C. & +++1 & 4 & 4 & 4 & $55555 \overline{5} 5321$ & 5555554321 \\
\hline $\mathrm{Cx} 24^{*}$ & Central nervous & 0 & N. C. & ++++ & 4 & 4 & 4 & $5554+310000$ & 5554321000 \\
\hline Cx31 & $\begin{array}{l}\text { Paresis } \\
\text { Past }\end{array}$ & 4 & N. C. & +++ & 4 & 4 & 4 & 5555521000 & $5 \operatorname{5in} 321000$ \\
\hline Dx14 ! & Paresis & 4 & N. C. & +++1 & 4 & 4 & 4 & $55 \overline{7} 4100000$ & $55554 \div 2100$ \\
\hline Dx19* & $\begin{array}{l}\text { Secondary neuro- } \\
\text { recurrence }\end{array}$ & 4 & N. C. & +++ & 0 & 4 & 4 & $55442+21100$ & 5553210000 \\
\hline Ex32 & Wassermann & 4 & 14 & ++ & 4 & 4 & 4 & 5442210000 & 5555432100 \\
\hline $\mathrm{F} \times 13^{*}$ & $\begin{array}{l}\text { Central nervous } \\
\text { system, treated }\end{array}$ & 0 & 5 & ++ & 0 & 4 & 4 & $554+4+4+21000$ & 5553210000 \\
\hline $\mathrm{F} \times 15^{*}$ & Paresis, treated & 0 & 2 & + & 0 . & 0 & 0 & 5555210000 & 5554321000 \\
\hline Kx13 & Nonsyphilitic? & 0 & N. C. & ++ & 0 & 0 & 0 & 5555432200 & 4321000000 \\
\hline 21 & Paresis & 4 & N. C. & $+t+t$ & 4 & 4 & 4 & 5555431000 & 5555432000 \\
\hline $\mathrm{Z3}$ & Paresis & 4 & 62 & ++++ & 4 & 4 & 4 & 5555432000 & 5555521000 \\
\hline $\mathrm{Z4}$ & Paresis & 4 & N. C. & +++ & d & 4 & 4 & 5555552100 & $555532100 n$ \\
\hline $\mathbf{Z}_{5}^{*}$ & Taboparesis & 0 & 20 & $+t+$ & 4 & 4 & 4 & 5554422100 & 5555532100 \\
\hline $\mathbf{Z 6}^{*}$ & Wassermann & 4 & N. C. & ++++ & 4 & 4 & 4 & 5555521000 & 55.25321000 \\
\hline Hx18 & Wassermann & 4 & 14 & ++++1 & 4 & 4 & 4 & 5542210000 & 5555321000 \\
\hline Hx23 & $\begin{array}{l}\text { Nonsyphilitic, leth- } \\
\text { argic encephalitis }\end{array}$ & 0 & 7 & $++t+1$ & 0 & 0 & 0 & 5433210000 & $554+3211000$ \\
\hline $\mathrm{Hx} 30$ & Central nervous & 4 & 11 & +++ & 0 & 3 & 4 & 5544320000 & 5554322100 \\
\hline Ix3 & $\begin{array}{c}\text { system, unclassed } \\
\text { Central nervous } \\
\text { system, meningo- } \\
\text { vascular }\end{array}$ & 2 & 26 & ++++ & 0 & 0 & 0 & 4442210000 & $553220<000$ \\
\hline Ix5 & Paresis & 4 & 20 & $+t+$ & 4 & 4 & 4 & $5555 \overline{3} 31100$ & 5552521000 \\
\hline $\mathrm{IX} 7$ & $\begin{array}{l}\text { Central nervous } \\
\text { system, vascular }\end{array}$ & 4 & 90 & +++ & 4 & 4 & 4 & 5444411000 & 4221000000 \\
\hline $\mathrm{Ix} 10$ & Tabes & 4 & 40 & +++ & 4 & 4 & 4 & 5554411000 & 5532100000 \\
\hline Ix11 & Tabes & 0 & 20 & ++ & 4 & 4 & 4 & 5543310000 & $54321000(10$ \\
\hline $\mathrm{Ix} 25$ & $\begin{array}{l}\text { Central nervous } \\
\text { system, unclassed }\end{array}$ & 4 & 0 & $++t$ & 3 & 4 & 4 & 5555422100 & 4321000000 \\
\hline $\begin{array}{l}\mathrm{Jx} 1^{*} \\
\mathrm{~J} \times 6\end{array}$ & $\begin{array}{l}\text { Secondary } \\
\text { Paresis }\end{array}$ & $\begin{array}{l}0 \\
.4\end{array}$ & $\begin{array}{r}98 \\
100\end{array}$ & $\begin{array}{l}++++ \\
+++t\end{array}$ & $\begin{array}{l}4 \\
4\end{array}$ & $\begin{array}{l}4 \\
4\end{array}$ & $\begin{array}{l}4 \\
4\end{array}$ & $\begin{array}{l}5555430000 \\
5555554320\end{array}$ & $\begin{array}{l}5532100000 \\
5555321000\end{array}$ \\
\hline $\mathrm{Jx} 24^{*}$ & $\begin{array}{l}\text { Central nervous } \\
\text { system, asympto- } \\
\text { matic, treated }\end{array}$ & 0 & 61 & $+++t$ & 4 & 4 & 4 & $4+4+44432+200$ & 5555321000 \\
\hline
\end{tabular}

* An asterisk after a case number signifles that the patient had been treated for syphilis by us.

* The globulin test was performed with Pandy's reagent. The Wassermann reactions were made with both plain alcoholic and 0.2 per cent. cholesterinized antigen.

* In this and the following tables, the diagnoses given are those made on the patient's admission, on the basis of clinical evidence. If neurologic symptoms or signs were absent, the diagnosis is allowed to remain unchanged, even when positive results in the spinal flujd examination show the presence of asymptomatic neurosyphilis.

Gold and Mastic Curves Both Paretic.-Of the thirty patients in the group (Table 1), only one was presumably nonsyphilitic; this was a case which had been diagnosed as lethargic encephalitis. In twentythree of the twenty-nine syphilitic patients there was definite clinical and serologic evidence of neurosyphilis (paresis 9, tabes 4, unclassed neurosyphilis 10 ), while the remaining six were diagnosed as asymp- 
tomatic neurosyphilis on the basis of blood tests and other spinal fluid abnormalities. A comparison of the gold and mastic curves in this group shows that they are almost parallel. The number of tubes in which complete precipitation occurred is sometimes greater with the gold, sometimes with the mastic test; but a fluid showing a very long or a very short paretic gold curve tends to show a mastic curve of the same general type.

Gold Curve Paretic, Mastic Curve Negative.-Only five patients fall into this group (Table 2). All of these patients were neurosyphilitic, and in all the clinical evidence, or that provided by other tests, showed that in these cases the gold curve is to be relied on rather than the mastic. Only one of the patients gave a positive Wassermann reaction of the spinal fluid, and at least two had normal cell counts.

Table 2.-Gold Curve Parftic; Mastic Curve Negative.

\begin{tabular}{|c|c|c|c|c|c|c|c|c|c|}
\hline \multirow{3}{*}{$\begin{array}{l}\text { Case } \\
\text { No. }\end{array}$} & \multirow{3}{*}{$\begin{array}{l}\text { Diagnosis on } \\
\text { Admission. } \\
\text { Form of } \\
\text { Syphilis }\end{array}$} & \multirow{3}{*}{$\begin{array}{c}\text { Blood } \\
\text { Wasser- } \\
\text { mann } \\
\text { Reac- } \\
\text { tion }\end{array}$} & \multicolumn{7}{|c|}{ Cerebrospinal Fluid } \\
\hline & & & \multirow[b]{2}{*}{ Cells } & \multirow{2}{*}{$\begin{array}{l}\text { Glob- } \\
\text { ulin }\end{array}$} & \multicolumn{3}{|c|}{ Wassermann } & \multirow{2}{*}{$\begin{array}{l}\text { Gold } \\
\text { Curve }\end{array}$} & \multirow{2}{*}{$\begin{array}{l}\text { Mastic } \\
\text { Curve }\end{array}$} \\
\hline & & & & & $\begin{array}{c}0.2 \\
\text { C.c. }\end{array}$ & $\begin{array}{c}0.4 \\
\text { C.c. }\end{array}$ & $\begin{array}{l}1.0 \\
\text { C.c. }\end{array}$ & & \\
\hline $\begin{array}{l}\mathrm{C} 14^{*} \\
\mathrm{R} 4^{*} \\
\mathrm{~S} 8^{*} \\
\rfloor \mathrm{X} 24\end{array}$ & $\begin{array}{c}\text { Tertiary } \\
\text { Wassermann } \\
\text { Tertiary } \\
\text { Central nervous }\end{array}$ & $\begin{array}{l}0 \\
3 \\
4 \\
4\end{array}$ & $\begin{array}{c}17 \\
41 \\
\text { N. C. } \\
0\end{array}$ & $\begin{array}{l}+\frac{ \pm}{+}+ \\
+\frac{t}{+}+\end{array}$ & $\begin{array}{l}0 \\
4 \\
0 \\
0\end{array}$ & $\begin{array}{l}0 \\
4 \\
0 \\
0\end{array}$ & $\begin{array}{l}0 \\
4 \\
0 \\
0\end{array}$ & $\begin{array}{l}4553221000 \\
5554210000 \\
4442100000 \\
5554310000\end{array}$ & $\begin{array}{l}2221000000 \\
2111000000 \\
2221100000 \\
211000000\end{array}$ \\
\hline$I x \geq 9$ & $\begin{array}{l}\text { system, unclassed } \\
\text { Central nervous } \\
\text { system, vascular }\end{array}$ & $?$ & 4 & + & 0 & 0 & 0 & 5443310000 & 2210000000 \\
\hline
\end{tabular}

Gold Syphilitic Zone, Mastic Negative.-There were twelve patients in this group (Table 3 ), two of whom were definitely nonsyphilitic (one a normal person, one a case of multiple sclerosis). There was confirmatory evidence of damage to the central nervous system in the fluid Wassermann reaction of only two patients, although in three others the globulin test was strongly positive. One of the patients with a positive fluid Wassermann reaction showed a persistently positive blood Wassermann reaction as the only clinical suggestion of neurosyphilis. In the other there was no clinical suspicion of central nervous system invasion. An additional patient had neurosyphilis which had been consistently treated. It is possible that the syphilitic zone gold curve in some members of this group may be explained if the gold test was performed three or four days after the spinal puncture. The fluid is usually not collected in sterile tubes, and bacterial contamination may play some part in the production of gold curves of this type. The presence of the curve in a normal patient in whom syphilis can be excluded lends support to some such explanation. 
Gold Syphilitic Zone, Mastic Paretic.-A comparison of this group with the last shows that in thirty-one instances in which a syphilitic zone gold curve was obtained, the mastic test was negative twelve times and paretic in type nineteen times. As stated in the foregoing, we have observed a syphilitic zone mastic curve only once. This was in a patient with cord tumor and xanthochromia. The spinal fluid showed no cells, a ++++ globulin reaction, a negative Wassermann test with all dilutions, a gold curve of the meningitic type reading 0001122411 , and a mastic curve* which read $224+5532100$.

In fifteen of the nineteen patients in this group (Table 4) there was definite clinical evidence of neurosyphilis; and in three of the remaining four the other tests in the fluid substantiated the diagnosis of neurosyphilis. The exception proved to be a case of lethargic

Table 3.-Gold Curve Syphilitic Zone, Mastic Negative

\begin{tabular}{|c|c|c|c|c|c|c|c|c|c|}
\hline \multirow{3}{*}{$\begin{array}{l}\text { Cast } \\
\text { No }\end{array}$} & \multirow{3}{*}{$\begin{array}{c}\text { Diagnosis on } \\
\text { Admission. } \\
\text { Form of } \\
\text { Syphilis }\end{array}$} & \multirow{3}{*}{$\begin{array}{l}\text { Blood } \\
\text { Wasser- } \\
\text { mann } \\
\text { Reac- } \\
\text { tion }\end{array}$} & \multicolumn{7}{|c|}{ Cerebrospinal Fluid } \\
\hline & & & \multirow[b]{2}{*}{ Cells } & \multirow{2}{*}{$\begin{array}{l}\text { Glob- } \\
\text { ulin }\end{array}$} & \multicolumn{3}{|c|}{ Wassermann } & \multirow{2}{*}{$\begin{array}{l}\text { Gold } \\
\text { Curve }\end{array}$} & \multirow{2}{*}{$\begin{array}{l}\text { Mastic } \\
\text { Curve }\end{array}$} \\
\hline & & & & & $\begin{array}{c}0.2 \\
\text { C.c. }\end{array}$ & \begin{tabular}{c|}
0.4 \\
C.c.
\end{tabular} & $\begin{array}{l}1.0 \\
\text { C.c. }\end{array}$ & & \\
\hline $\mathrm{H} 6^{*}$ & Wassermann & 1 & N. C. & ++ & 0 & 0 & 0 & 2321000000 & $22100000<0$ \\
\hline W11* & Wassermann & 2 & 13 & \pm & 1 & 2 & 3 & 1123000000 & 2211200000 \\
\hline$A \times 4^{*}$ & Wassermann & 0 & N. C. & $\frac{1}{0}$ & 0 & 0 & 0 & $223+3+110000$ & 2211100000 \\
\hline $\mathrm{Bx} 15^{*}$ & Secondary & 4 & N. C. & + & 1 & 4 & 4 & 1123110000 & 2222100000 \\
\hline $\mathrm{Dx} 4^{*}$ & Wassermann & 0 & N. C. & \pm & 0 & 0 & 0 & 2355110000 & 210000000 \\
\hline Dx 5* & Secondary & 0 & N. C. & $+\dot{\bar{t}}+$ & 0 & 0 & 0 & 2233100000 & 2220000000 \\
\hline Dxi6* & Wassermann & 4 & N. C. & ++++ & 0 & 0 & 0 & 2343100000 & 2211000000 \\
\hline Ex19* & $\begin{array}{c}\text { Central nervous } \\
\text { system }\end{array}$ & 0 & 0 & + & 0 & 0 & 0 & 1233332000 & 2210000000 \\
\hline $\mathrm{Ix} 1^{*}$ & Wassermann & 0 & 2 & + & 0 & 0 & 0 & 1233332000 & 1000000000 \\
\hline $\mathrm{Ix} 6$ & $\begin{array}{c}\text { Nonsyphilitic, } \\
\text { normal }\end{array}$ & 0 & 0 & 0 & 0 & 0 & 0 & 2332200000 & 1000000000 \\
\hline$A \times 17^{*}$ & Secondary & 0 & N. C. & $+t$ & 0 & 0 & 0 & 2445522100 & 2111000000 \\
\hline $\mathrm{J} \times 28$ & $\begin{array}{l}\text { Nonsyphilitic, } \\
\text { multiple sclerosis }\end{array}$ & 0 & 2 & + & 0 & 0 & 0 & $12332+00000$ & 2210000000 \\
\hline
\end{tabular}

encephalitis. In general, the paretic mastic curves obtained here were of a shorter type than those in the group in which the gold curve was also paretic.

These results permit the conclusions that a paretic type of mastic curve is even less significant of paretic neurosyphilis than a paretic gold curve; that it is commonly obtained in other types of neurosyphilis ; and that it may be found, as may a similar gold curve, in nonsyphilitic neurologic diseases. In only two patients in this group was even a preliminary diagnosis of paresis permissible. However, in our opinion, it must be accepted that a paretic mastic test obtained in a syphilitic patient is indicative of definite damage to the central nervous system.

Gold Curve Negative, Mastic Paretic.-The fact that seventeen of the total number of patients studied have shown colloidal tests of this type lends support to the argument that the mastic test should occupy a more prominent place in the routine examination of the 
cerebrospinal fluid. Inspection of the data regarding these seventeen patients (Table 5) shows that in eleven there was clinical evidence sufficient to support a diagnosis of neurosyphilis; in eleven the Wassermann test of the spinal fluid was also positive. Only three patients showed neither definite clinical nor other serologic evidence of central nervous system invasion.

Mastic Curve "3", Showing Moderate Precipitation in the First Few Tubes; Gold Curve of Various Types.-This group, comprising twenty-four cases, is of especial interest because of the borderline type of the mastic curve (Table 6). They were divided clinically as follows: primary syphilis, 1 ; secondary, 5 ; tertiary, 5 ; latent, 1 ; Was-

Table 4.-Gold Curve Syphilitic Zone, Mastic Curve Paretic

\begin{tabular}{|c|c|c|c|c|c|c|c|c|c|}
\hline \multirow{3}{*}{$\begin{array}{l}\text { Case } \\
\text { No. }\end{array}$} & \multirow{3}{*}{$\begin{array}{c}\text { Diagnosis on } \\
\text { Admission. } \\
\text { Form of } \\
\text { Syphilis }\end{array}$} & \multirow{3}{*}{$\begin{array}{c}\text { Blood } \\
\text { Wasser- } \\
\text { mann } \\
\text { Reac- } \\
\text { tion }\end{array}$} & \multicolumn{7}{|c|}{ CerebrospinaI Fluid } \\
\hline & & & \multirow[b]{2}{*}{ Cells } & \multirow{2}{*}{$\begin{array}{l}\text { Glob- } \\
\text { ulin }\end{array}$} & \multicolumn{3}{|c|}{ Wassermann } & \multirow{2}{*}{$\begin{array}{l}\text { Gold } \\
\text { Curve }\end{array}$} & \multirow{2}{*}{$\begin{array}{l}\text { Mastic } \\
\text { Curve }\end{array}$} \\
\hline & & & & & $\begin{array}{c}0.2 \\
\text { C.c. }\end{array}$ & $\begin{array}{l}0.4 \\
\text { C.c. }\end{array}$ & $\begin{array}{l}1.0 \\
\text { C.c. }\end{array}$ & & \\
\hline $\mathrm{C4}^{*}$ & Wassermann & 0 & 8 & + & 0 & 0 & 0 & 0113110000 & $43: 2111000$ \\
\hline $\mathrm{A} \times 26^{*}$ & $\begin{array}{l}\text { Central nervous } \\
\text { system, meningitis }\end{array}$ & 0 & N. C. & ++ & 0 & 0 & 0 & 2223222100 & 5543100000 \\
\hline $\mathbf{B} \times 29^{*}$ & Secondary & 0 & N. C. & ++ & 0 & 0 & 1 & 1112333000 & 5432110000 \\
\hline $\mathrm{Cx}^{*}$ & $\begin{array}{l}\text { Central nervous } \\
\text { system, meningeal }\end{array}$ & 0 & 12 & ++ & 0 & 3 & 4 & 2222411000 & 5310000000 \\
\hline Cx17 & $\begin{array}{l}\text { Paresis } \\
\text { P }\end{array}$ & 4 & N. C. & $+++t$ & 4 & 4 & 4 & 1123221000 & 5554321000 \\
\hline $\mathrm{Cx} 22^{*}$ & $\begin{array}{l}\text { Central nervous } \\
\text { system, meningeal }\end{array}$ & 0 & N. C. & ++ & 0 & 0 & 0 & 3345210000 & 5543210000 \\
\hline $\mathrm{E} \times 14^{*}$ & Wassermann & 4 & 943 & $+t+t$ & 4 & 4 & 4 & 0123330000 & 5555322100 \\
\hline $\operatorname{Ex} 20$ & $\begin{array}{c}\text { Unclassed (enceph- } \\
\text { alitis?) }\end{array}$ & 0 & 2 & +++ & 0 & 0 & 0 & 2244441110 & 5543211000 \\
\hline $\operatorname{Ex} 28^{*}$ & Wassermann & 0 & N. C. & + & 1 & 3 & 4 & 1232221000 & 4321000000 \\
\hline $\mathrm{F} \times 10^{*}$ & Secondary & 0 & 8 & ++ & 0 & 1 & 4 & $2+3+32+110000$ & 5543200000 \\
\hline $\mathrm{Fx} 23$ & $\begin{array}{l}\text { Central nervous } \\
\text { system, unclassed }\end{array}$ & 0 & 8 & ++++ & 4 & 4 & 4 & 2223341000 & 5554321000 \\
\hline $\mathrm{Gx} 6$ & Central nervous & 4 & 0 & +++ & 0 & 2 & 4 & 1223321000 & 4322100000 \\
\hline Gx11 & $\begin{array}{l}\text { system, unclassed } \\
\text { Tertiary }\end{array}$ & 4 & 26 & $+t+$ & 0 & 0 & 0 & 1133211000 & 4432210000 \\
\hline $\mathrm{Gx} 23^{*}$ & Tabes & i) & 5 & $++t+$ & 0 & 0 & 4 & 2244210000 & 5543210000 \\
\hline Gx28 & $\begin{array}{l}\text { Central nervous } \\
\text { system, 8th nerve }\end{array}$ & 0 & 6 & $++t+$ & 2 & 3 & 4 & 2332100000 & 5542210000 \\
\hline Gx31 & Wassermann & 4 & 102 & $++t+$ & 4 & 4 & 4 & 1123210000 & $554+2100000$ \\
\hline $\mathrm{Hx} 12$ & Paresis & 4 & 73 & $+t+t$ & 4 & 4 & 4 & 2441111000 & 44555553210 \\
\hline $\mathrm{H} \times 29^{*}$ & Central nervous & 0 & 35 & $++t$ & 0 & 2 & 4 & 3333421000 & 5552221000 \\
\hline Z2 & $\begin{array}{c}\text { system, unciassea } \\
\text { Tabes }\end{array}$ & 4 & N. C. & ++++ & 2 & 4 & 4 & $2+443100000$ & 5554321000 \\
\hline
\end{tabular}

sermann positive, 7 ; cerebrospinal syphilis, 4; and nonsyphilitic, 1. Eighteen had received antisyphilitic treatment prior to the examination of the fluid. In only three instances was the Wassermann test of the fluid positive in any dilution. In one of these (P3) the gold curve was paretic in type; in another case (GX1) it was negative, although the globulin reaction was +++ ; and in a third (GX22) it was of the syphilitic zone type. In one case (AX7) the gold test gave a high syphilitic zone curve; the clinical diagnosis was neurosyphilis unclassed. In a case (CX18) with vascular neurosyphilis, the gold curve was also of the syphilitic zone type. One patient (DX9) was nonsyphilitic and had lethargic encephalitis; and seven showed no clinical or other 
serologic evidence of neurosyphilis, rendering the value of the mastic test doubtful in those cases. In the remaining eleven patients, however, there were either. clinical signs strongly suggesting neurosyphilis, or a definitely abnormal cell count and globulin content, or both. To sum up: In seventeen of the twenty-four cases in this group, other evidence of central nervous system invasion in addition to the borderline mastic test was present, while in seven cases such confirmatory evidence was absent. This leads to the conclusion that a mastic test of this type must be interpreted only in connection with the other clinical and serologic findings, but that in general it may be considered as a definite abnormality. It is of interest that in only four fluids showing

Table 5.-Gold Curve Negative, Mastic Curve Paretic

\begin{tabular}{|c|c|c|c|c|c|c|c|c|c|}
\hline \multirow{3}{*}{$\begin{array}{l}\text { Case } \\
\text { No. }\end{array}$} & \multirow{3}{*}{$\begin{array}{c}\text { Diagnosis on } \\
\text { Admission. } \\
\text { Form of } \\
\text { Syphilis }\end{array}$} & \multirow{3}{*}{$\begin{array}{c}\text { Blood } \\
\text { Wasser- } \\
\text { nuann } \\
\text { Reac- } \\
\text { tion }\end{array}$} & \multicolumn{7}{|c|}{ Cerebrospinal Fluid } \\
\hline & & & \multirow[b]{2}{*}{ Cells } & \multirow{2}{*}{$\begin{array}{l}\text { Glob- } \\
\text { ulin }\end{array}$} & \multicolumn{3}{|c|}{ Wassermann } & \multirow{2}{*}{$\begin{array}{l}\text { Gold } \\
\text { Curve }\end{array}$} & \multirow{2}{*}{$\begin{array}{l}\text { Mastic } \\
\text { Curve }\end{array}$} \\
\hline & & & & & $\begin{array}{l}0.2 \\
\text { C.c. }\end{array}$ & $\begin{array}{l}0.4 \\
\text { C.c. }\end{array}$ & $\begin{array}{l}1.0 \\
\text { C.c. }\end{array}$ & & \\
\hline $\begin{array}{r}\text { B19 } \\
\text { M10 }\end{array}$ & $\begin{array}{c}\text { Wassermann } \\
\text { Oentral nervous } \\
\text { system, meningeal }\end{array}$ & $\begin{array}{l}4 \\
0\end{array}$ & N. ${ }^{7}$. & $\underset{++}{ \pm}$ & $\begin{array}{l}4 \\
0\end{array}$ & $\begin{array}{l}4 \\
2\end{array}$ & $\begin{array}{l}4 \\
4\end{array}$ & $\begin{array}{l}1222100000 \\
1112100000\end{array}$ & $\begin{array}{l}5543210000 \\
5543100000\end{array}$ \\
\hline Ax15* & $\begin{array}{c}\text { Tabes } \\
\text { Tystem }\end{array}$ & 0 & N. C. & + & 4 & 4 & 4 & 0112221100 & 4553110000 \\
\hline $\mathrm{Cx} 3$ & Congenital & 4 & N. C. & $+++t$ & 4 & 4 & 4 & 0112211100 & 5553321000 \\
\hline $\mathrm{Cx} 23^{*}$ & Secondary & 0 & N. C. & \pm & 0 & 0 & 0 & 01.22100000 & 4322100000 \\
\hline Dx8* & Primary & 4 & N. C. & $\mp$ & 0 & 0 & 0 & 1111000000 & 4321000000 \\
\hline Dx $28^{*}$ & $\begin{array}{l}\text { Secondary, neuro- } \\
\text { recurrence }\end{array}$ & 0 & N. C. & ++ & 0 & 4 & 4 & 0111110000 & 5422100000 \\
\hline Ex4 & Tertiary & 4 & 9 & 0 & 0 & 0 & 0 & 0111110000 & 4321000000 \\
\hline Ex $18^{*}$ & Tabes & 0 & 2 & +++ & ; & 3 & 4 & 1222211100 & $35554+21000$ \\
\hline Ex31 & $\begin{array}{c}\text { Central nervous } \\
\text { system }\end{array}$ & 4 & 16 & +++ & 4 & 4 & 4 & 1222210000 & 5543221000 \\
\hline $\mathbf{F x} 16^{*}$ & Wassermann & $?$ & 2 & + & 0 & 0 & 0 & 1112210000 & 4321100000 \\
\hline Fx26 & Tabes & 0 & 2 & $+t+t$ & 0 & 1 & 4 & 0112110000 & 4332100000 \\
\hline $\mathrm{H} \times 5$ & Wassermann & 4 & 65 & ++++ & 1 & 4 & 4 & 2211000000 & 5543210000 \\
\hline $\mathrm{H} \times 6$ & $\begin{array}{l}\text { Central nervous } \\
\text { system, vascular }\end{array}$ & $?$ & 23 & $+4+$ & 0 & 0 & 0 & 1112221000 & 4553210000 \\
\hline $\mathrm{I} \times 14^{*}$ & Central nervous & 4 & 4 & ++ & 0 & 4 & 4 & 1222110000 & 4322000000 \\
\hline $\mathrm{I} \times 17$ & $\begin{array}{l}\text { system, unclassed } \\
\text { Secondary }\end{array}$ & 4 & 14 & +++ & 4 & 4 & 4 & 2222200000 & 4322000000 \\
\hline $\mathrm{Ix} 18$ & $\begin{array}{c}\text { Central nervous } \\
\text { system (?), Bell's } \\
\text { palsy }\end{array}$ & 0 & 13 & $+t$ & 0 & 0 & 0 & 0001100000 & $432: 20000 \mathrm{~L} 0$ \\
\hline
\end{tabular}

this type of mastic curve was the gold curve abnormal. Perhaps changes may occur in the mastic test before they appear in the gold, and in treated neurosyphilis it may be that the mastic test is rendered negative more slowly than is the gold. Further study of this type of reaction is necessary before its interpretation can be safely determined.

\section{DISCUSSION}

A general survey of the whole material shows that in 108 cases in which abnormalities appeared in one or both colloidal tests, there was complete agreement (both curves paretic in type) only thirty times. There were seventeen instances in which the gold test was positive (five paretic, twelve syphilitic zone) when the mastic test was negative. At least a few of the gold curves of the latter type may be questioned 
because of possible bacterial contamination of the fluid. On the other hand, in seventeen cases the mastic curve was paretic when the gold was negative, and in all of these cases it appeared to be more closely in agreement with the clinical and serologic evidence provided. In the group of twenty-four borderline mastic curves, the evidence appears to favor the gold four times, and the mastic thirteen times, while in seven instances the result is doubtful. We must emphasize once more the relation of the paretic curves of both colloids to paresis. So far as the gold curve is concerned, practically all cases of paresis show a paretic curve, but this type of curve is frequently found in other types

Table 6.-Gold Curve of Various Types; Mastic “3” Curve

\begin{tabular}{|c|c|c|c|c|c|c|c|c|c|}
\hline \multirow{3}{*}{$\begin{array}{l}\text { Case } \\
\text { No. }\end{array}$} & \multirow{3}{*}{$\begin{array}{l}\text { Diagnosis on } \\
\text { Admission. } \\
\text { Form of } \\
\text { Syphilis }\end{array}$} & \multirow{3}{*}{$\begin{array}{c}\text { Blood } \\
\text { Wasser. } \\
\text { mann } \\
\text { Reac- } \\
\text { tion }\end{array}$} & \multicolumn{7}{|c|}{ Cerebrospinal Fluid } \\
\hline & & & \multirow[b]{2}{*}{ Cells } & \multirow{2}{*}{$\begin{array}{l}\text { Glob- } \\
\text { ulin }\end{array}$} & \multicolumn{3}{|c|}{ Wassermann } & \multirow{2}{*}{$\begin{array}{l}\text { Gold } \\
\text { Curve }\end{array}$} & \multirow{2}{*}{$\underset{\text { Curve }}{\text { Mastic }}$} \\
\hline & & & & & $\begin{array}{c}0.2 \\
\text { C.c. }\end{array}$ & $\begin{array}{c}0.4 \\
\text { C.c. }\end{array}$ & $\begin{array}{l}1.0 \\
\text { C.c. }\end{array}$ & & \\
\hline P3* & W asserm unn & 0 & N. C. & $+t$ & 2 & 4 & 4 & 5555431000 & 3322110000 \\
\hline R5* & Tertiary & 0 & N. 0 . & 0 & 0 & 0 & 0 & 1121000000 & 3221100000 \\
\hline S10* & Wassermann & 4 & N. C. & + & 0 & 0 & 0 & 0112100000 & 3221110000 \\
\hline Ax5* & Tertiary & 4 & N. $\mathrm{C}$. & \pm & 0 & 0 & 0 & 1222000000 & 3222111000 \\
\hline Ax7 & Central nervous & 0 & N. C. & $\mp$ & 0 & 0 & 0 & $111254+5100$ & 3322111000 \\
\hline $\mathrm{Cx}^{* *}$ & Tertiary & 0 & N. C. & \pm & 0 & 0 & 0 & 0012211000 & 3332110000 \\
\hline $\mathrm{Cx} 18$ & Oentral nervous & 4 & N. C. & $\bar{T}$ & 0 & 0 & 0 & 0123111000 & 3221000000 \\
\hline $\mathrm{Cx} 19^{*}$ & Central nervous & 0 & 13 & +++ & 0 & 0 & 0 & 0011110000 & 3221000000 \\
\hline Cx:1* & $\begin{array}{l}\text { system } \\
\text { Secondary }\end{array}$ & 0 & N. C. & 0 & 0 & 0 & 0 & 0002200000 & 3210000000 \\
\hline $\mathrm{Cx} 25$ & Latent & 0 & N. C. & 0 & 0 & 0 & 0 & 1121100000 & 3210000000 \\
\hline $\mathrm{Cx} 26^{*}$ & Wassermann & 0 & N. C. & 0 & 0 & 0 & 0 & $112+1100000$ & 3221000000 \\
\hline () $22^{*}$ & Tertiary & 3 & N. C. & + & 0 & 0 & 0 & 0001000000 & 3221100000 \\
\hline Dx9 & $\begin{array}{l}\text { Nonsyphilitie, leth- } \\
\text { argic encephalitis }\end{array}$ & 0 & N. 0 . & + & 0 & 0 & 0 & 1221000000 & 3210000000 \\
\hline $\mathrm{D} \times 31^{*}$ & Wassermann & 4 & 8 & $+t$ & 0 & 0 & 0 & 0111100000 & 3210000000 \\
\hline $\mathrm{F} \times 1^{*}$ & Wassermann & 4 & 5 & $+t$ & 0 & 0 & 0 & 1121000000 & 3210000000 \\
\hline $\mathrm{Ex} 13^{*}$ & Wassermann & ) & 3 & $+t$ & 0 & 0 & 0 & 0112000000 & 3221000000 \\
\hline Fx8* & Secondary & () & 2 & $\begin{array}{l}1 \\
+\end{array}$ & 0 & 0 & 气 & 1211000000 & 3221000000 \\
\hline Fx12* & Secondary & () & 2 & ++ & 0 & 0 & 0 & $11111+00000$ & 3222000000 \\
\hline $\mathbf{F x} 14^{*}$ & Primary & 6) & 15 & ++ & 0 & 0 & 0 & 0011110000 & 3222000000 \\
\hline $\mathbf{G X 1}^{*}$ & Secondary & 0 & 3 & $++t$ & 0 & 0 & 4 & 1111110000 & 3221000000 \\
\hline $\mathbf{G x 3}$ & Tertiary & 4 & 3 & \pm & 0 & 0 & 0 & $111+1+1+10000$ & 3221000000 \\
\hline Gx5 & Wassermann & 4 & 1 & $\bar{T}$ & 0 & 0 & 0 & 0111111000 & 3211000000 \\
\hline $\mathrm{G} \times 22$ & Central nervous & 4 & 42 & ++ & 1 & 4 & 4 & $23+3+1100000$ & 3221000000 \\
\hline $\mathrm{Ix} 4^{*}$ & $\begin{array}{l}\text { system, vascular } \\
\text { Secondary }\end{array}$ & 0 & 3 & + & 0 & 0 & 0 & 1110000000 & 3221000000 \\
\hline
\end{tabular}

of neurosyphilitic involvement. A paretic type of mastic curve also appears in most cases of paresis, but it is found even more frequently than the gold in other neurosyphilitic diseases. A diagnosis of paresis is therefore never permissible solely on the basis of a paretic mastic curve.

We have no explanation to offer for our failure to obtain mastic curves of the syphilitic zone type, unless, as suggested by Stanton, ${ }^{3}$ variations in the lot of mastic used is responsible. We have employed four lots of mastic from different sources, with almost equally satisfactory results in three. One lot was found to react in the usual way but not to a sufficient degree, and was therefore discarded. 
We feel, however, that the information provided by the mastic test, while in our hands it does not precisely parallel that afforded by the gold test, is of value in the examination of spinal fluids of syphilitic patients. In a considerable number of cases, it has been found to be positive when the gold test was negative.

\section{CONCLUSION}

The results which we have obtained show that there is a fairly close parallelism between the colloidal gold and the colloidal mastic tests; and that when agreement is lacking, the mastic test seems to detect abnormalities more frequently than does the gold. This fact, and the simplicity of performance of the mastic test, lead us to conclude that the test should be an indispensable part of the routine of spinal fluid examinations. 